\title{
Balıkçılığın eski Anadolu toplumlarındaki yeri
}

\section{Illkem Gürgör ${ }^{*} \oplus$, İsmail Özer ${ }^{2}$}

${ }^{1}$ M.A., Doktor adayı | Ankara Üniversitesi, Sosyal Bilimler Enstitüsü, Paleoantropoloji Bilim Dalı, Ankara / TÜRKiYE ${ }^{2}$ Prof. Dr. | Ankara Üniversitesi, Dil ve Tarih - Coğrafya Fakültesi, Antropoloji Bölümü, Ankara / TÜRKIYE
* Sorumlu Yazar / Corresponding Author:

Illkem Gürgör

Ankara Üniversitesi, Sosyal Bilimler Enstitüsü Antropoloji Anabilim Dalı, Paleoantropoloji Bilim Dalı Dil ve Tarih - Coğrafya Fakültesi 06100 Sıhhiye, Ankara / TÜRKIYE E-posta: ilkemgurgor@gmail.com

Alındı/Received: 6 Nisan / April 2020 Düzeltildi/Revised: 22 Aralık / December 2020

Kabul/Accepted: 23 Aralık / December 2020

Yayımlandı/Published: 30 Aralık / December 2020

\section{Öz}

Bu çalışmada, Anadolu'da Paleolitik Çağ’dan günümüze gelinceye kadar balık ve balıkçılığın yeri araştırılmıştır. Bu makalede incelenen alan, Akdeniz, Karadeniz, Marmara Denizi ve Ege Denizi ile çok sayıda iç suların dahil olduğu su habitatlarını içermektedir. Bu ortamlar, genis spektrumlu ekonomilerin ortaya çıkmasına katkıda bulunan, kalıcı olarak veya deniz yoluyla istismar edilmiş olabilecek çeşitli sucul beslenme kaynakları sunmuştur. Yapılan çalışmalar, balıkçılığın tarihöncesi dönemlerden itibaren Anadolu'da yaşayan toplumların ekonomik ve sosyal yașamlarında önemli bir yer tuttuğunu göstermiștir. Bu doğrultudaki çalışmalarda yaygın biçimde sazan, yayın, çipura, turna balı̆̆, orkinos, kefal gibi balıklar ve midye, istiridye, dikenli salyangoz gibi denizel omurgasızlara ait buluntular tespit edilmiștir. Balık buluntularının, balık istismarını ve balıkçlık pratiklerinin boyutunu anlamanın yan sıra, ticarî ilişkiler ve kurban ritüellerindeki rolünü belgelemek adına da oldukça önemli olduğu anlaşılmıştır.

Anahtar Sözcükler: Balıkçlık, beslenme, zooarkeoloji, eski Anadolu toplumlar1

\section{Giriş}

İnsanlar ve çevre, sürekli bir döngü içinde birbirlerini etkiler ve birbirlerine karșllik verir. İnsan-çevre etkileşimleri ve çevreyle ilgili insan eylemlerinin yansımaları, özellikle insanların hangi hayvanları tükettikleri konusunda aldıkları kararlar aracılığıyla incelenebilir. Günlük olarak, insanlar çevredeki mevcut tüm kaynaklar arasından kullanmak ve diyetlerine dâhil etmek için hayvanları seçerler. Paleolitik Çağ’da avcıllk ile, Neolitik Çağ ve sonrasında ise evcilleştirme ile hayvanları besin diyetlerinin en önemli basamağına yerleştirmişlerdir. Geçmiş insan popülasyonları ve hayvan toplulukları arasındaki etkileşim, zooarkeoloji olarak bilinen ve arkeolojik alanlardan ele geçen hayvan kalıntılarının (kemikler, dişler ve kabuklar) incelenmesi olarak tanımlayabileceğimiz bilim dalı aracılığıyla araştırılır (Reitz ve Wing, 1999).

Zooarkeolojik çalıșmalar sonucunda, Anadolu'daki

\section{The place of fishery in ancient Anatolian populations Abstract}

In this study, the place of fish and fishery has been investigated from the Paleolithic Age until today. The area examined in this article includes the Mediterranean, Black Sea, Marmara Sea and Aegean Sea, and aquatic habitats including many inland waters. These environments provided a variety of aquatic feeding resources that could have been exploited permanently or by sea, contributing to the emergence of broadspectrumed economies. The zooarchaeological studies have shown that fishery bave an important place in the economic and social lives of the societies living in Anatolia since the prehistoric times. In line with these studies, carp, catfish, gilt-head bream, pike, tunny, grey mullet and invertebrates such as mussels, oyster, murex and carb were found. In addition to understanding fish abuse and the extent of fishing practices, it has been found to be very important in documenting its role in commercial relations and sacrificial rituals.

Key Words: Fishery, diet, zooarchaeology, ancient Anatolian populations

arkeolojik kazılarda ele geçirilen hayvan kemikleri arasında pek çok yerleşim ve dönemde ilk sırayı koyun, keçi, sığır ve domuzun aldığ1 tespit edilmiştir (Gürgör, 2017). Her ne kadar karasal hayvanların insan ekonomik ve sosyal yaşantısının önemli bir bölümünü oluşturduğu görülse de balık ve diğer denizel ürünlerin de azımsanmayacak derecede önemli olduğu, gerçekleştirilen çalışmalar neticesinde ortaya konmuştur. Balıkçl1ık muhtemelen, bugün olduğu gibi birçok tarih öncesi insanın yaşamında ve geçiminde de önemli bir rol oynamıștır.

Tarihöncesi dönemlerde et için avlanma ve toplama odaklı ekonomik örgütlenme, insanların günlük yaşantılarının önemli bir bölümünü oluşturmuştur. Çeşitli araştırmalar balık tüketiminin tahmin edilenden daha erken başladığını göstermektedir. Deniz, nehir ya da göl balıkçllı̆ı̆ın popülasyonların sadece beslenmesine değil, aynı zamanda gelișmesine de izin 
veren temel ve optimal bir strateji olduğu da açktır (Yesner, 1980; Van Neer, 1986; Gautier ve Van Neer, 1989; Stewart, 1989; Rick ve Erlandson, 2000; Rick vd., 2001). Bu nedenle, dünyanın farklı yerlerinde bazı küçük ölçekli ticari balıkçıların hâlâ uyguladı̆̆ı gibi, erken dönem balıkçılığının da çok sayıda insanı bir araya getiren bir toplanmayı içerdiği öngörülmektedir.

Bu çalışmada Anadolu'da Paleolitik Çăğ'dan Osmanlı Dönemi'nin sonuna kadar geçen zaman dilimlerine ait yerleşim yerlerindeki kazı çalışmalarında elde edilen denizel buluntular incelenerek, temelde toplumlarin paleodiyetleri ve buradan yola çıkarak sosyokültürel özelliklerinin ortaya konulması amaçlanmıştır.

\section{Gereç ve yöntem}

Bu makalede incelenen coğrafya, Akdeniz, Karadeniz, Marmara Denizi ve Ege Eenizi ile çok sayıda iç suların dâhil olduğu su habitatlarını barındırmaktadır. $\mathrm{Bu}$ ortamlar, insan toplumlarında geniş spektrumlu ekonominin ortaya çıkmasına katkıda bulunan çeşitli sucul beslenme kaynakları sunmuştur. Bu çalışmada Anadolu'da, prehistorik ve protohistorik çağlarda hem tuzlu hem de tatlı sulardaki balıkçılık faaliyetlerine genel bir bakış sunularak, eski Anadolu yerleşimlerinde bulunan balık ve yumuşakça kalıntılarının sağladığ1 kanıtlara dikkat edilmiştir. Bu doğrultuda, balık avlama ve avlanma faaliyetleri, balığı saklama şekilleri ile balıkla ilișkili dinsel ritüeller de ele alınmıștır. Bunlara ek olarak, buluntuların hangi türe ait olduğunun anlaşılmasıly, bu balıkların ticarî faaliyetlerdeki rollerinin de ortaya konulması amaçlanmıştır.

Balıkçılığın Anadolu'daki öneminin belirlenmesine yönelik yaptığımız bu çalışmada 83 adet arkeolojik buluntu alanından elde edilen veriler değerlendirilmiştir
(Tablo 1). Her lokalite için dönem ve denizel ürün buluntu sayısı (kaynakta bahsi geçiyorsa) belirtilmiştir.

Kazıda bulunan balık ve kabukluların az sayıda olması toplumların denizel ürünlerden faydalanmadığ1 anlamını taşımaz. Sayısal verinin az olmasına neden olan etmenlerden biri, kazıdaki toplama yöntemidir -ki buluntuların elle toplanması, kimi zaman büyük malzemenin seçilip küçük olan kemiklerin gözden kaçmasına neden olmaktadır. Özellikle kırılgan ve gözden kaçabilecek durumda olan kemikler için kazılarda kuru veya 1slak elek yöntemi ya da yüzdürme metodu tercih edilmelidir. Eleme yöntemleriyle elde edilen daha çok buluntu türlerin çeşitliliği ve iskeletin daha çok parçayla temsili gibi olumlu sonuçlara yol açmaktadır. Bir diğer sorun ise, kazı sırasında toplanan balık kemiklerinden tür tayini yapmak için uygun referans koleksiyonun yetersiz oluşu ya da kazıda bir zooarkeoloğun bulunmaması nedeniyle tür tanımlamalarının büyük ölçüde zorlaşmasıdır (Silibolatlaz Baykara, 2019). Bu, geniş bir coğrafî bölgeyle uğraştı̆̆ımız gerçeğiyle birleştiğinde (Harita 1), eski balıkçılık uygulamalarının belgelenmesini ve insan beslenmesinde balığın öneminin anlaşılmasını daha da zorlaştırmaktadır.

Bahsedilen bu önyargılara rağmen, bu çalışmada balık kullanım modelleri ve balıkçlık tekniklerindeki değişiklikleri açıklamak için tür zenginliğindeki (Tablo 1) ve düşük dereceli avlara kıyasla yüksek dereceli balıkların nispî bolluğundaki çeşitliliği incelenmeye çalışılmıştır. Zooarkeolojik alanların pek çoğunda sayısal verilere yer verilmemesi, buluntuların genel olarak sadece tanımlar üzerinden değerlendirilmesi çalışmamızı zorlaştırmış olsa da, bu çalışmanın özellikle Anadolu'da geçmiş dönemlerden itibaren balıkçılık faaliyetlerinin anlaşılması ve seyri adına önemli olduğunu düşünmekteyiz.

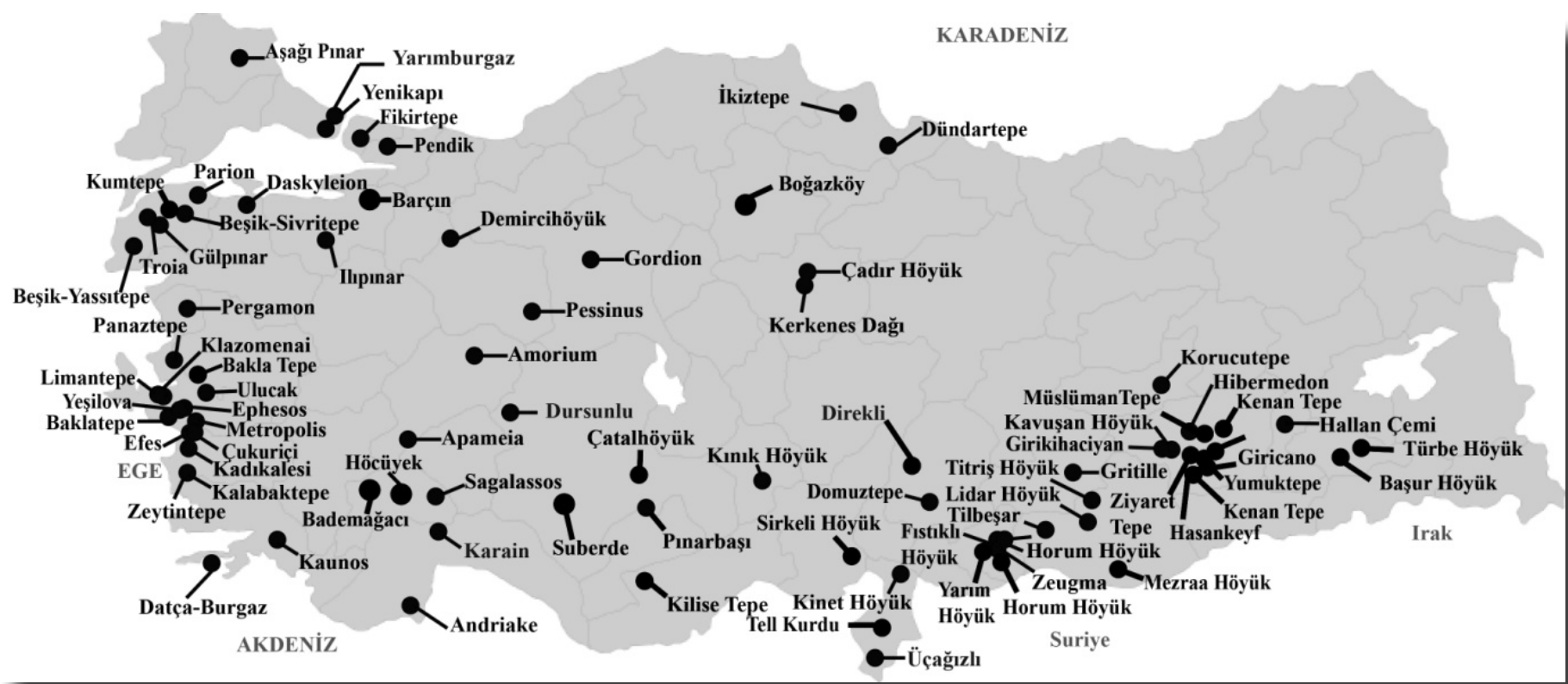

Harita 1. Paleolitik Çağ’dan günümüze Anadolu yerleşimlerinde bulunan su ürünlerinin listesi 
Tablo 1. Paleolitik Dönem'den günümüze Anadolu yerleşimlerinde bulunan su ürünlerinin listesi

\begin{tabular}{|c|c|c|c|}
\hline Buluntu alanı & Dönem & Say1 & Zooarkeolojik buluntular \\
\hline Dursunlu & Paleolitik Çă̆ & & Monodonta \\
\hline Yarımburgaz & Paleolitik Çă̆ & & Pisces sp. \\
\hline Karain & Paleolitik Çağ & & Pisces, Crustacea \\
\hline Üçağızlı & Paleolitik Çă̆ & & $\begin{array}{l}\text { Pisces, Nassarius gibbosula, Patella, Columbella rustica, Dentat } \\
\text { Gibbula sp., Theodoxus jordani }\end{array}$ \\
\hline Öküzini & Üst Paleolitik Çăg & & Pisces sp. \\
\hline Direkli & Epipaleolitik Çă̆ & & Pisces sp. \\
\hline Pınarbaşı Kaya Sığınağ1 & Epipaleolitik Çağ & 190 & $\begin{array}{l}\text { Nassarius gibbosula, Columbella rustica, Dentalium, Juniperus, } \\
\text { Helianthemum sp., Silene sp., Caryophyllaceae, Atriplex/ Cher } \\
\text { spp. Pistacia sp., Lens sp., Leguminosae, Asteraceae, Arne } \\
\text { Lithospermum sp., Alkanna sp., Labiatae, Plantago sp., As } \\
\text { Galium sp., Eleocharis sp., Cladium mariscus, Bolboschoenus } \\
\text { Schoenus sp., Carex sp., Hordeum sp., Phalaris arundinacea, F } \\
\text { Puccinellia sp., cf. Phragmites australis }\end{array}$ \\
\hline Hallan Çemi Tepesi & Epipaleolitik Çağ & & Catfish and cyprinid \\
\hline Göbekli Tepe & Neolitik Çă̆ & & Cyprinid, Silurus \\
\hline Hallan Çemi & Neolitik Çă̆ & & Siluriformes, Cyprinidae, Unio tigridis, Unio valves \\
\hline Hasankeyf & Neolitik Çă̆ & & Unio tigridis, Unio valves \\
\hline Mezraa Teleilat & Neolitik Çă̆ & & Pisces sp. \\
\hline Aşıklı Höyük & Neolitik Çă̆ & 2 & Pisces sp. \\
\hline
\end{tabular}

Doğu Çatalhöyük

Suberde

Barçın Höyük

Höyücek

Bademağac1

Fikirtepe

Pendik

Domuztepe

Ilipinar

Ulucak

Yeşilova
Neolitik Çă̆

Neolitik Çă̆

Neolitik Çă̆

Neolitik Çă̆

Kalkolitik Çă̆

Kalkolitik Çă̆

Kalkolitik Çă̆

Kalkolitik Çă̆

Kalkolitik Çă̆

Kalkolitik Çă̆

Theodoxus of. heldreichi heldreichi Viviparus viviparus, Bythinella cf. Turca, Bythinella leachi, Valvata piscinalis, Fagotia esperi, Lymnaea stagnalis, Stagnicola palustris, Radix auricularia, Planorbis carinatus, Gyraulus crista, Planorbarius corneus, Columbella rustica, Nassarius gibbosula, Conus mediterraneus, Antalis sp., Vallonia pulchella, Borlumastus yildirimi, Cecilioides sp., Monacha rothii, Xeropicta derbentina

Pisces sp.

Viviparus sp., Flexopecten glaber, Helix, Unio, Mytilus edulis, Ostreidae Conus sp., Strombus bubonius Cyprae, Murex, Helix, Glycymeris Tinca sp. Chrysophrys aurata, Sparus pagrus Pisces sp. Pisces sp.

Cyprinidae, Helix aspersa, Gastropoda Mollusca, Buccinidae, Turridae, Mytilidae, Cerastoderma (Cardium) edule, Ostrea edulis, Unio sp., Potamon potamios

Pisces sp.

Hexaplex trunculus, Bolinus brandaris, Ostrea edulis, Unio sp., Cerastoderma glaucum, Arca noae, Callista chione, Spondylus gaederopus, Cerithium vulgatum, Patella sp., Pectinidae 
Tablo 1. Paleolitik Dönem'den günümüze Anadolu yerleşimlerinde bulunan su ürünlerinin listesi (devamı)

\section{Buluntu alanı}

Dönem

Çukuriçi

Kalkolitik Çağ

\begin{tabular}{|c|c|}
\hline Aşağ1 Pınar & Kalkolitik Çağ \\
\hline Girikihaciyan & Kalkolitik Çağ \\
\hline Domuztepe & Kalkolitik Çă̆ \\
\hline F1stıklı Höyük & Kalkolitik Çağ \\
\hline Gülpınar & Kalkolitik Çağ \\
\hline Kumtepe & Kalkolitik Çağ \\
\hline Bakla Tepe & Kalkolitik Çağ \\
\hline Yumuktepe & Kalkolitik Çă̆ \\
\hline Kenan Tepe & Kalkolitik Çă̆ \\
\hline Tell Kurdu & Kalkolitik Çă̆ \\
\hline Mezraa Höyük & Kalkolitik Çă̆ \\
\hline Yarım Höyük & Kalkolitik Çă̆ \\
\hline Demircihöyük & Erken Tunç Çağ1 \\
\hline Tilbeşar & Tunç Çağ1 \\
\hline Kilisetepe & Tunç Çağ1 \\
\hline Korucutepe & Tunç Çağ1 \\
\hline İkiztepe & Tunç Çağ1 \\
\hline Dündartepe & Tunç Çağ1 \\
\hline Titriş Höyük & Tunç Çağ1 \\
\hline Lidar Höyük & Tunç Çağ1 \\
\hline Beşik Sivritepe & Tunç Çağ1 \\
\hline Beşik Yassitepe & Tunç Çağ1 \\
\hline Liman Tepe & Tunç Çağ1 \\
\hline Panaztepe & Tunç Çağ1 \\
\hline
\end{tabular}

Troia

Say1

Zooarkeolojik buluntular

Hexaplex trunculus, Bolinus brandaris, Helix cincta, Helix sp., Donacilla cornea, Buccinilum cornea, Turritella communis, Mytilus galloprovincialis, Ostrea edulis, Unio crassus, Mytilus cf. galloprovincialis, Cerastoderma glaucum, Arca noae, Barbatia barbata, Tapes decussatus, Venus verrucosa, Spondylus gaederopus, Gourmya vulgata, Patella cerulea, Patella ferruginea,

Patella sp., Oxychilus, Solen sp., Monodonta articulata, Monodonta turbinata, Gibulla sp., Columbella rustica, Hinia reticulata, Tonna galea, Trochoidea trochoides

Cardium edule, Unio crassus, Mytilus of. galloprovincialis

Pisces sp., Crustecae

Pisces sp.

Pisces sp.

Pisces sp.

Ostrea plicata, Mytilus edulis

Pisces sp., Bivalvia

Pisces sp., Mollusca

Pisces sp.

Siluridae

Mollusca

Pisces sp., Mollusca

Cyprinus carpio

Potamon potamios

Tatlı su ve ithâl denizel türler

Pisces sp., Unio mussels

Pisces sp

Bivalvia

1

442

Tunç Çağ1
Osteichthyes, Lamniformes, Bivalvia, Naticidae, Gastropoda, Decapoda

Silirus triostegus, Cyprinid

Thunnus thynnus, Scombridae, Sparus aurata, Argyrosomus regius, Bivalvia, Osteridae

Epinephelus margitanus

Sparus aurata, Pagrus pagrus, Lambridae, Epinephelus, Cerastoderma, Conus sp.

Cyprinidae, Mugilidae, Sparus aurata, Glcymeris, Charonia, Columbella, Ensis, Murex, Cerithium, Patella, Ostrea, Mactra, Donax, Spondylus sp., Pinna sp., Cerastoderma, Unio

Pisces sp. 
Tablo 1. Paleolitik Dönem'den günümüze Anadolu yerleşimlerinde bulunan su ürünlerinin listesi (devamı)

\begin{tabular}{|c|c|c|c|}
\hline Buluntu alanı & Dönem & Say1 & Zooarkeolojik buluntular \\
\hline Baklatepe & Tunç Çağı & & Pisces sp. \\
\hline Ephesos & Tunç Çağ1 & & Mollusca \\
\hline Giricano & Tunç Çağ1 & & Crustacea, Mollusca \\
\hline Kenan Tepe & Tunç Çağ1 & & Pisces sp., Crustacea, Mollusca \\
\hline Müslüman Tepe & Tunç Çağ1 & & Pisces sp., Mollusca \\
\hline Hirbemerdon & Tunç Çağ1 & & Pisces sp., Mollusca \\
\hline Başur Höyük & Tunç Çağ1 & & Crustacea \\
\hline Türbe Höyük & Tunç Çağ1 & & Mollusca \\
\hline Ziyaret Tepe & Tunç Çağ1 & & Pisces sp., Gastropoda sp., Unio sp. \\
\hline Horum Höyük & Tunç Çağ1 & & Cyprinus carpio, Mollusca \\
\hline Sirkeli Höyük & Orta-GeçTunç Çağ1 & & Epinephelus marginatus, 1 yerel Ciarias, 1 ithâl denizel tür \\
\hline Boğazköy-Aşağ1 Şehir & Orta-GeçTunç Çağ1 & 8 & Selachimorpha, yerel tatlı su ve ithâl denizel tür \\
\hline Kaman-Kalehöyük & Geç Tunç Çağ1 & & Pisces sp. \\
\hline Gordion & Geç Tunç Çağ 1 & 17 & Pisces sp. \\
\hline Panaztepe & Demir Çağ1 & & Cardium \\
\hline Hirbemerdon & Demir Çağ1 & & Pisces sp. \\
\hline Kavuşan Höyük & Demir Çağ1 & & Pisces sp. \\
\hline Kerkenes Dağ1 & Demir Çağı & & Delphinidae \\
\hline Kalabaktepe & Antik Çağ & & Sparus aurata \\
\hline Zeytintepe & Antik Çağ & & Abranis brama, Selachimorpha \\
\hline Troia & Antik Çă̆ & & Scombridae \\
\hline Daskyleion & Antik Çağ & & Siliuridae, Bivalvia \\
\hline Pergamon & Antik Çağ & & Abranis brama, Bivalvia \\
\hline Datça-Burgaz & Antik Çağ & & Shell \\
\hline Ephesos & Antik Çağ & & $\begin{array}{c}\text { Cyprinus carpio, Abramis brama, Rutilus frisii, Sander lucioperca, Clarias } \\
\text { sp., Squalus acanthias, Chondrichthyes, Pleuronectiformes, Muarena belena, } \\
\text { Labrus } \mathrm{sp} .\end{array}$ \\
\hline Gordion & Antik Çağ & & Pisces sp. \\
\hline Zeugma & Antik Çağ & & Unio sp., Bivalvia \\
\hline Pessinus & Antik Çağ & & $\begin{array}{l}\text { Cyprinidae, Ostrea edulis, Helix sp., Cyprinus carpio, Silurus glanis, } \\
\text { Esox bucius }\end{array}$ \\
\hline Apamêe & Antik Çağ & & Pisces sp., Mollusca \\
\hline Kaunos & Antik Çă̆ & & Mytilus edulis, Pteriomorpha, Tritonium tritonidis \\
\hline
\end{tabular}


Tablo 1. Paleolitik Dönem'den günümüze Anadolu yerleşimlerinde bulunan su ürünlerinin listesi (devamı)

\begin{tabular}{|c|c|c|c|}
\hline Buluntu alanı & Dönem & Say1 & Zooarkeolojik buluntular \\
\hline Beşik-Sivritepe & Antik Çă̆ & & Bivalvia, Bagrus, Cardium sp. \\
\hline Sagalassos & Antik Çağ & & Lates niloticus \\
\hline Klazomenai & Antik Çă̆ & & $\begin{array}{r}\text { Sparus aurata, Patelladiae, Cerithium sp., Hexaplex trunculus, Fasciolaria } \\
\text { cf. lignaria, Arca noe, Pinna sp., Pectinidae, Spondylus gaederopus, Ostrea } \\
\text { edulis, Cerastoderma glaucum }\end{array}$ \\
\hline Parion & Antik Çă̆ & & Bivalvia \\
\hline Metropolis & Antik Çağ & & Ostrea edulis, Venus verrucosa, Heraplex trunculus, Mytilus galloprovicialis \\
\hline Yenikap1 & Bizans Dönemi & & $\begin{array}{c}\text { Cyprinidae, Sparidae, Carcharbinidae, Dicentrarchus labrax, Clarias sp., } \\
\text { Thunnus thunynnus, Sarda sarda, Scomber sp., Xiphias gladius, Silurus } \\
\text { sp., Epinephelus sp., Rajiformes, Tursiops truncatus, Delphinus delphis, } \\
\text { Crustacea }\end{array}$ \\
\hline Pessinus & Bizans Dönemi & 154 & $\begin{array}{c}\text { Sparidae, Cyprinidae, Carcharbinidae, Lamnidae, Sciaenidae, } \\
\text { Epinephelidae, Dicentrarchus sp., Balistidae }\end{array}$ \\
\hline Çadır Höyük & Bizans Dönemi & & Cyprinidae, Balistidae \\
\hline Ephesos & Bizans Dönemi & 109 & $\begin{array}{c}\text { Epinephelus, Sparus aurata, Moronidae, Scombridae, Mugil cephalus, } \\
\text { Chelon labrosus, Abranis brama, Cyprinus carpio, Barbus sp., Scorpaena } \\
\text { sp., Labridae }\end{array}$ \\
\hline Amorium & Bizans Dönemi & & Pisces sp. \\
\hline Sagalassos & Bizans Dönemi & 182 & $\begin{array}{c}\text { Epinephelus, Auxis rocher, Sarda sarda, Cyprinus carpio, Vimba vimba, } \\
\text { Esox lucius, Silurus glanis, Clarias sp. }\end{array}$ \\
\hline Beşik-Sivritepe & Bizans Dönemi & & Thunnus thynnus, Argyrosomus regius, Sparus aurata \\
\hline Kadıkalesi & Bizans Dönemi & & Pisces sp., Mollusca \\
\hline Andriake & Bizans Dönemi & 4899 & $\begin{array}{l}\text { Thais haemastoma, Hexaples trunculus, Murex brandis, Cardium sp., } \\
\text { Buccinulum cornium, Monodonta sp. }\end{array}$ \\
\hline Kinet Höyük & Selçuklu Dönemi & & Pisces sp. \\
\hline Gritille & Selçuklu Dönemi & & Potamon \\
\hline Horum Höyük & Selçuklu Dönemi & & Cyprinus carpio, Unio sp., Crustacea \\
\hline Kınık Höyük & Selçuklu Dönemi & & Pisces sp. \\
\hline Korucutepe & Selçuklu Dönemi & & Pisces sp., Unio sp. \\
\hline Pergamon & Selçuklu Dönemi & & Cyprinus carpio, Abramis brama, Clarias sp. \\
\hline Ephesos & Selçuklu Dönemi & & Clarias sp. \\
\hline
\end{tabular}

\section{Bulgular ve Değerlendirme}

Genel olarak baktığımızda arkeolojik alanlardan toplanan balık kalıntılarının sinırlı sayıda olduğu görülmektedir. Eski Anadolu toplumları üzerinde yapılmış çalışmalarda iç kesimlerdeki lokalitelerde de balık kalıntıları bulunmasına rağmen, sayı kıyı kesimlerindeki yerleşim yerlerine göre oldukça düşüktür. Bu çalışmada örneklem büyüklükleri genellikle çok sınırlı olduğundan ve aile düzeyinin ötesindeki tanımlamalar nadir olduğundan, dikkatli örneklemenin ve ayrıntılı analizin gerçekleştirildiği birkaç bölgeye odaklanılmıştır.

\section{Paleolitik ve Epipaleolitik Çağlar}

Yapılan araştırmalar balıkçıllı̆̆n insan beslenmesinde önemli bir yeri olduğunu gösterse de buluntu alanlarryla ilişkili olarak bu döneme ilişkin zooarkeolojik verilerimiz oldukça kısıtlıdır. Paleolitik Çağ sucul kalıntıları Anadolu'da, Dursunlu, Yarımburgaz, Karain, Üçağızlı ve Öküzini mağaralanında tespit edilmiştir. Karain ve Öküzini mağaralanında bulunan kemiklerin hangi balık türlerine ait olduğu belirtilmemişse de bunların büyük olasılıkla Anadolu'da en çok tüketilen balık türleri olan 
sazan ve yayın olduğu tahmin edilmektedir (Van Neer vd., 2005). Üst Paleolitik ve Epipaleolitik Çağ insanlarının yaşam biçimleri ve ekonomik yapılanmalarının anlaşılması bakımından Akdeniz Levant Bölgesi'nde yer alan Üçağızlı Mağarası özellikle büyük önem taşımaktadır. Üçağızlı'da bulunan sucul hayvanlara ait buluntular ağırlıklı olarak Patella ve Monodonta cinslerine aittir.

Epipaleolitik Çă̆'da ise Direkli, Pınarbaşı Kaya Sı̆̆ınağı, Hallan Çemi Tepesi’nde balık kalıntıları ele geçirilmiştir. Yine Epipaleolitik yerleşimi olan ve M.Ö. 10190-9800 yılları arasına tarihlendirilen Körtik Tepe'de insanların beslenmesinde daha çok balıkçlık ve toplayıcılığın rol oynadığı, ele geçirilen çok sayıda deniz kabukları sayesinde tespit edilebilmiştir (Benz vd., 2013). Bir başka araştırmada, Pınarbaşı'nda balıkların insan diyetine katkıda bulunduğu, kemiklerin sıklı̆̆ına bakıldığında bu katkının Boncuklu'dan biraz daha az olduğuna vurgu yapılmıştır (Baird vd., 2018).

\section{Neolitik Çăg}

Yapılan literatür araştırmaları, Neolitik Çă̆ balıkçılık aktiviteleri ile ilgili bilgilerin çok sınırlı olduğunu göstermektedir (Tablo 1). Doğu Anadolu'da Hallan Çemi, Hasankeyf, Mezraa-Teleilat, Orta Anadolu'da Pınarbaşı A, Çatalhöyük, Suberde, Akdeniz'de Höyücek, Bademağacı ile Marmara'da Barçın Höyük bu dönemde balık avcılığına yönelik verilerin elde edildiği yerleşimlerdir. Çatalhöyük’te özellikle küçük balıklar için yoğun balık tüketiminin olduğuna dair önemli kanıtlar elde edilmiştir. Yerleşkede, 65 farklı alanda 16000 balık kalıntısı tespit edilmiştir. Yapılan çalışmalarda sazangiller (Cyprinidae) familyasına ait kalıntıların oldukça fazla olduğu anlaşılmıştır. Bol miktarda balık kalıntısı bulunmasına karşın, olta malzemelerine yönelik veriler nadirdir. Bulunan tek bir balık kancası yüksek olasılıkla büyük sazan balıklarının avlanmasında kullanılmıştır. Büyük miktarlardaki çipura ve sazan balık avcılığının sepet ve ince örgülü ağlar yardımıyla gerçekleştiği düşünülse de şu ana kadar bulunan sepetlerin hiçbiri balıkçlık ile ilişkilendirilememiştir (Van Neer vd., 2016).

\section{Kalkolitik Çăg}

Neolitik Çağ’da görülmeye başlanan küçük köy yerleşimleri, Kalkolitik'te artarak devam etmiş, etrafı duvarlarla çevrili yeni yapılar kurulmuştur. M.Ö. 50003000 yılları arasına tarihlendirilen Kalkolitik Çăg, kentleşmenin ilk safhalarının görülmeye başlandığı bir dönemdir (Silibolatlaz Baykara, 2012). Kiyısal bölgeleri içine alan Batı Anadolu ve Marmara Havzası'ndaki yerleşimlerde bu dönemde yapılan balıkçılık faaliyetlerine ilişkin önemli veriler elde edilmiştir.

Kuzeybatı Anadolu'nun geçim kalıpları açısından önemli bir özelliği, balıkçllı ve yumuşakça toplamaya ilişkin verilerin çeşitliliğidir. Orta-Batı Anadolu ve Göller
Bölgesi'ndeki alanlarda deniz veya göl kaynaklarının kullanıldığına dair bazı kanıtlar bulunsa da özellikle kıy yerleşimlerinde deniz faunası tüketimi oldukça yüksektir. Burada, yumuşakça toplama ve açık deniz balıkçılığ1, av hayvanları ile birlikte g1da ekonomisinin önde gelen faaliyetleri olmuştur (Boessneck ve von den Driesch, 1979). Kalkolitik Çağ'da balıkçılık faaliyetlerinin anlaşılmasına yönelik önemli alanlar Fikirtepe, Ilıpınar, Çukuriçi ve Pendik Höyük'tür. Fikirtepe yerleşmesinde saptanabilen tuzlu su balıkları deniz turnas1 (Merluccius merluccius), kefal (Mugil sp.), levrek (Dicentrarchus labrax), mercan balığ1 (Sparus auratus), bir tür deniz melanuryas1 (Sparidae), fulya balğ1 (Johnius bololepidotus), dikenli uskumru (Carangidae) ve Tuna balığ1 (Thunnus thynnus) gibi türlerinden oluşmaktadır. Tatlı su balıkları ise Karadeniz kızıl kanadı (Rutilus frisii), döbel (Leuciscus cehpalus), kocaağız (Aspius aspius), bir tür sazan (Cyprinidae), yayın balığ1 (Silurus glanis), turna balığ1 (Esox lucius), uzun levrek (Lucioperca lucioperca) türleridir. Bunların dışında yerleşmede bir de açık deniz canlısı olan yunus (Tursiops truncatus) kemikleri açığa çıkarılmıştır (Gölbaş, 2016). Kabuklu su ürünlerine ait istiridye (Ostrea edulis), kara kabuk midyesi (Mytilus edulis), kalp midyesi (Acanthocardia tuberculata) gibi türler saptanmıştır. Yumuşakçaların miktarları, Fikirtepe yerleşmesindeki balıkçılığın daha çok yumuşakça toplayıcılığı biçiminde yapıldığına işaret etmektedir. Ilıpınar'da ise pek çok kabuklu deniz hayvanı, Çukuriçi'nde ise çipura, yılan balığ1 ve iskaroz gibi balıkların yanı sıra pek çok farklı türde denizel yumuşakça ele geçirilmiştir. Pendik Höyük'te ise balıkçılık ve yumuşakça toplayıcıllğıyla ilgili en önemli kanıtlar 2 adet olta kancası, çeşitli olta ve ă̆ ağırlıkları ve boncuk olarak kullanılan deniz kabuklarıdır. Yerleşimin kurulduğu dönemdeki denize olan mesafesi net olarak tespit edilebilmiş olmasa da Pendik yerleşmesi günümüzde denize çok yakın bir konumda yer almaktadır. Tespit edilen balık türleri ise Fikirtepe'de bulunanlar ile tamamen aynıdır. Yalnızca tuna balığ1 ve yunus (Tursiops truncatus) burada görülmemiştir

\section{Tunç Çağı}

Erken Tunç Çağı'ndan itibaren Anadolu kıyı bölgesi boyunca yoğun bir yerleşim gözlenmektedir. Buna rağmen, çoğu bölgede balık buluntu ve avcıllı̆ına yönelik verilerin sınırlı olduğu anlaşılmaktadır. Ele alınan bölgenin batı ucunda, Troia ve yakınlardaki BeşikYassitepe bölgeleri, yaygın olarak tuna balığı, kılıç balığ1 ve büyük köpek balıkları olmak üzere geniş pelajik ${ }^{1}$ balıkların yaygın olarak kullanıldığını belgelemektedir. En önemli kıyı balık taksonları, izmarit ve hani balığıgiller familyasına aittir. Troia'da, lagünler de balıkçılıkta yoğun

\footnotetext{
${ }^{1}$ Hayatlarının büyük bölümünü su yüzeyi ile dip arasındaki serbest su kütlesi içerisinde geçiren, çoğunluk göçmen olan, belirli bir yere bağımlı olmayan balıklardır.
} 
bir şekilde kullanılmış, ancak avlanma yerleri, nehrin çökmesi sonucu önemle azalmıştır. Bu durum Erken Tunç Çağı'ndan Klasik Dönem'e kadar balık faunasında takip edilebilmektedir (Van Neer vd., 2016).

Erken Tunç Çağı'na tarihlenen Tatıka mezarlık alanında bulunan balık kemikleri iki adet vertebra ile temsil edilmektedir. Yapilan incelemeler sonucunda ele geçirilen bubalıktürünün sazangiller familyasından Barbus lacerta'ya ait olduğu tespit edilmiştir. Orta Tunç ve Geç Tunç Çağı'na tarihlendirilen Panaztepe katmanlarında ise, pek çok deniz canlısı örneği bulunmuştur. Bunların arasında baskın olan tür kum midyesidir (Cerastoderma). Panaztepe, Anadolu'da yapılan zooarkeolojik çalışmalar içerisinde en çok deniz ürününe sahip yerlerden biri olması bakımından büyük bir öneme sahiptir. Toplam 10545 denizel omurgasız, 25 kabuklu canlı ve 10 tane balık kalıntısının etüdünün yapıldığı belirtilmektedir (Reese, 2006). Akdeniz kıyısından $40 \mathrm{~km}$ içeride yer alan Kilise Tepe ile yine kıyıdan $20 \mathrm{~km}$ uzaklıkta yer alan Sirkeli Höyük'te Akdeniz balığı kalıntılarına rastlanmıştır (Van Neer v.d., 2004).

\section{Demir Çăgı}

Bu döneme ilişkin ele geçirilen balık kalıntıları oldukça az sayıda olsa da Akdeniz'in merkez ve doğusunda yer alan Demir Çağı yerleşimlerinden elde edilen balık kalıntıları bölgesel balıkçılık hakkında bilgi edinmemize imkân tanımaktadır. Yapılan çalışmalarda Panaztepe'de kalp midyesi (Cardium) ve Kerkenes Dağı'nda yunusgiller (Delphinidae) familyasına ait veriler elde edilmiştir (Tekkaya, 1992). Akdeniz’in kuzeydoğu köşesinde yer alan liman yerleşmesi Kinet Höyük'te de (M.Ö. 1200-400) balık ve kabuklu deniz ürünlerinin yerleşim sakinlerince tüketildiğini göstermektedir. Çoğunlukla Epinephelus cinsine ait olan bu balık kemiklerinin üzerinde tespit edilen sistematik kesim izleri, büyük boyutlu balıkların baş kısımlarının gövdelerinden farklı bir şekilde tüketilmek üzere işlemden geçirildiği anlaşılmıştır. Bu tüketim şekli Doğu Akdeniz toplumları açısından benzersizdir (Çakırlar vd., 2014). Bunlara ek olarak, Maydos Kilisetepe'de yapılan çalışmalar yaklaşık 6687 adet buluntuyu gün yüzüne ç1karırken, bölgedeki Tunç ve Erken Demir Çağı toplumlarının balıç̧lık faaliyetlerine yönelik önemli kantlar sunmuştur. Bivalvia, Gastropoda, Osteichthyes ve Chondrichthyes kazı çalışmaları sonucunda bulunan deniz canlılarıdır (Badem, 2019).

\section{Antik Çăg}

Hayvancilık ekonomisi hakkında çeşitli yerleşimlerden gelen zooarkeolojik veriler ve yazll metinler, Anadolu Roma Dönemi'ndeki pastoral uygulamaların anlaşılmasının yolunu açmıştır. Roma Dönemi'ne ilişkin yerleşimlerde sazangiller, yayıngiller ve turna balığıiller (Esocidae) ailelerine ait kalıntılar ele geçirilmiştir. $\mathrm{Bu}$ türler, hem tarihöncesi çağlarda hem de Klasik Dönem'de en çok avlanan balıklar arasindadirlar. Sardalya, levrek, uskumru ve çipura da Roma Dönemi'nde tüketilen balıklar arasında sayılabilir. Müren balığ1 da Roma Dönemi'nde tüketilmiştir. Anadolu kıyı bölgelerinin dişında iç kesimlerde de balık kalıntılarına rastlanmıştır. Ele geçirilen tatlı ve tuzlu su balıklarının Akdeniz kıyılarından getirtilmiş olabileceği düşünülmektedir (Bursa, 2007). İmparatorluk dönemi boyunca balık tuzlama, balık sosu ve murex üretimine dair kalıntılar Fas, İspanya ve Britanya'nın Atlantik kıyllarında kaydedilmiştir (Kay, 2014).

Balık kolay bozulan bir besin olsa da tuzlama ve sos yapımı ile kullanım ömrü artırılmıştır. Soslar arasında en ünlüsü ise, balıklardan yapılan garum'dur². Yazılı kaynaklar Anadolu'da özellikle Klazomenai Antik Kenti'nin bu sos ile ünlü olduğunu açığa çıkarmıştır (Yıldırım, 2010). Bu dönemde deniz kaynaklarının üretiminde çeşitli gelişmeler gözlenmiştir. Birinci yüzyllın ikinci yarısından itibaren tank, baraj sistemleri ve kanallar gibi etkileyici tarım sistemleri, balık yetiştiriciliği için Akdeniz kıyılarında kullanılmaya başlanmıştır. Antik kaynaklar teknolojik açıdan gelişmiş, nitelikli avcıların özellikle balıkların göç vakitlerinde Karadeniz ve Doğu Akdeniz gibi kıyı bölgelerinde ton balığı avlama amaçlı seferler düzenlediklerine işaret etmektedir.

\section{Orta Çăg}

Bat1 Roma İmparatorluğu'nun çöküşü ile İstanbul'un fethi arasında kalan dönem Orta Çağ olarak adlandırılır. Bu dönemde hareketli pastoral yaşamla bağlantıll olarak az sayıda yerleşim görülmüştür. Anadolu'da bu dönemde Doğu Roma ya da Bizans ve onun etkilendiği kültürlerin yansımaları görülmüştür. Bizans Dönemi’ndeki balıkçılık faaliyetlerinin anlaşılmasında Yenikapı'da yapılan çalışmaların önemi büyüktür. Çalışmalar sonucunda farklı balık türlerine bolca rastlanmış, üzerlerindeki kesik izleri incelenmiş ve sonuç olarak yazılı metinlerde de sıkça bahsedilen Byzantion'un "tuna balığ metropolisi” olarak isimlendirilmesi zooarkeolojik kanitlarla da desteklenmiştir (Onar, 2013).

Sagalassos'ta Bizans Dönemi'ne ilişkin yapılan kazı çalışmaları, balıkçılık ekonomisinin önemini ortaya koymuştur. Kazılar, tatlı ve tuzlu su balıklarının varlığını ortaya koyarken, bazı balıkların ticaretinin yapıldığ1 da anlaşılmıştır. Sazan, yayın, çapak, turna balı̆̆ı, tatlı su kefali, eğrez Sagalassos halkı tarafindan tüketilmiştir. Bunların dışında orkinos, palamut, sardalya, gobene gibi

\footnotetext{
Balığın eti, yumurtası, iç organları ve kanının tuzlu suda mayalanması sonucu olușan, hazırlanması hayli zor olan sosun adıdır. Roma Dönemi'nde bu sosun hazırlanmasında pek çok farklı türde balık kullanılmıştır (Aksoy vd., 2016).
} 
balıklar da yapılan kazı çalışmaları sonucu Sagalassos antik yerleşmesinde ortaya çıkarılmıştır (Bursa, 2007).

Bizans'ta balık, diğer besin g1daları ile birlikte önemli rol oynamıştır. Özellikle tuzlanmış balık, ekmek ve et ile birlikte Anadolu Bizans'ında sofralarda yer almıştır. Sazan, yayın, turna balığ1, Afrika kedi balı̆̆ı, orkinos ve kılıç balığı avlandığı, ele geçirilen balık kılçıklarının analiz edilmesiyle anlaşılmıştır. Bu türlere ait ele geçirilen kalıntılarda pek çok kasaplık izlerine rastlanmış olması, Anadolu Bizans Dönemi'nde balığın yemek kültüründe önemli bir rolü olduğuna işaret etmektedir. Sadece kıyı bölgelerde yaşayanlar değil, iç bölgelerdeki nehir, lagün ve göl kaynaklarına yakın yerleşmelerde de kent sakinleri balık avcılığı yapmışlar, avladıklarını hem beslenme hem ticari amaçlı kullanmışlardır. Bu dönemde kent etrafındaki çeşitli tatlı su kaynakları, B12, magnezyum ve çeşitli vitaminler açısından zengin balıklara ev sahipliği yapmiştır (Bursa, 2007). Kabuklu su ürünleri de Bizans Dönemi'ndeki önemli besin maddelerindendir. 1213. yüzyılda bu hayvanlar "meleklerin besini" olarak adlandırılmıs ve manastırlara yılın belirli vakitlerinde hediye olarak sunulmuştur (Doğer ve Armağan, 2014). Her ne kadar antik kaynaklar deniz kabuklularının kullanımından bahsetse de bu dönemdeki zooarkeolojik veriler Yenikapı ile sınırlı kalmaktadır.

Bizans İmparatorluğu'nun zayıflamasıyla Anadolu toprakları Selçuklular'a hem kültürel hem politik anlamda kapılarını aralamıştır (Yakar, 2007). 1071 yılında Malazgirt Savaşı ile toprakların hâkimiyeti büyük ölçüde Selçuklular'ın eline geçmiş, bundan 3 yil sonra da Anadolu Selçuklu Devleti kurulmuştur. Zooarkeolojik verilerin büyük çoğunluğu Anadolu akınlarını takiben gelse de, balıkçlık ekonomisi ve bu dönemdeki hareketlilik ile ilgili olarak oldukça az miktarda veri bulunmaktadir. Yapılan çalışmalarda Kinet Höyük'te Pisces sp., Horum Höyük'te sazan ve tatlı su midyelerine, Gritille'de tatlı su yengecine ilişkin kalıntılara rastlanmıştır (Stein, 1998; Bartosiewicz, 2005). Pergamon'da sazan, çapak balığ1 ve hava soluyan yayıngillere yönelik veriler elde edilmiştir. Selçuklu Dönemi’nde devletin güney sınırını Murat Nehri, batı ve güneybatı sınırını ise Firat Nehri çizmektedir. Yukarı Dicle Havzası'na kadar uzanan Korucutepe her ne kadar nehir kaynaklarına yakın olsa da balıkçılığın beslenme için yeteri kadar değer görmediği anlaşılmıştır. Kazılar sonucu tanımlanamayan balık ve midye türlerinin ele geçirildiği belirtilmektedir (Boessneck ve von den Driesch, 1974).

Türklerin Anadolu'ya gelişi sosyal, ekonomik, politik ve demografik değişikliklere yol açmıştır. En erken ve somut tarihsel veriler, büyük ve güçlü kabile birliklerinin göçünün Anadolu'nun sosyal ve ekonomik yapısı üzerinde önemli değişimlere yol açtı̆̆ını göstermektedir. Zooarkeolojik kanıtların büyük çoğunluğu Anadolu akınlarını takiben gelse de, hayvancılık ekonomisi ve bu dönemdeki hareketlilik ile ilgili olarak oldukça az miktarda veri bulunmaktadır. Yerleşmelerin büyük çoğunluğu bozkır bitki örtüsüne sahip, dolayısıyla koyun ve sığır yetiştiriciliğine olanak sağlayan Orta Anadolu platolarında yoğunlaşırken, kentlerin genel olarak küçük ölçekli tarım ve hareketli hayvancilik ekonomisi üzerine odaklanmış bir ekonomik yapıya sahip oldukları düşünülmektedir. 1112. yüzyıllar, Anadolu topraklarında bu yeni gurubun neden olduğu sosyoekonomik değişimler için önemli kanitlar sunmaktadir (Hammer ve Arbuckle, 2017). Anadolu'da yerleşik halde bulunan topluluklar, Orta Asya steplerinden gelen göçebe toplulukların beslenme kültürlerinden etkilenmişler, dolayısıyla bu karma sosyal yapıya sahip toplulukların kültürlerinden harmanlanmış ve zenginleşmiş yeni bir mutfak anlayışı doğmuştur. Yemek kültürüne ilişkin metinsel kaynaklardaki bilgilere Kaşgarlı Mahmut'un Divanu Lügatt'i Türk, Evliya Çelebi’nin ve İbn-i Battuta'nın Seyahatnâmesi, Yusuf Has Hacib'in Kutatgu Bilig ve Mevlana'nın Mesnevi, Mektübat ve Mecalis-i Seb'a ile Dede Korkut hikayelerinden ulaşılabilmektedir (Akın vd., 2015; Düzgün ve Özkaya, 2015). Zooarkeolojik bulgular ise Gritille, Horum Höyük, Kinet Höyük, Pergamon ve Ephesos'tan gelmektedir.

Osmanlı Dönemi balıkçılık ekonomisinin esasları ile ilgili bilgilerimiz çeşitli Osmanlı dokümanlarından gelmektedir. İstanbul'un alınmasından önceki dönemlere ilişkin verilerimiz ise oldukça kısıtlıdır. Daha sonraki dönemlere ilişkin genellikle devlet merkezli bilgilere ise gümrük kayıtları, arazi, nüfus ve gelir kaynaklarının araştırmaları (tahrir defterleri), bütçe ve mühimme defterlerinden ulaşılabilmektedir (Fleet, 2014).

İstanbul'un fethedilmesiyle birlikte yemek kültüründe de farklılaşmalar gözlemlenmiştir. Örneğin, Bizans etkisiyle birlikte balık daha çok tüketilmeye başlanmiştır (Güler, 2010). Her ne kadar nüfusun çoğunluğu İslamî bir anlayışa sahip olsa da Osmanlı İmparatorluğu karmaşık bir demografik yapıya sahiptir ve bu da pek çok kültürün bu topraklarda harmanlanması demektir (Hongo, 1997). Bu döneme ilişkin en önemli arkeolojik belge, 20. yüzyıl başlarında Osmanlı İmparatorluğu Balıkhane Müdürü olarak görev yapan Karekin Deveciyan'1n tüm Osmanlı İmparatorluğu sınırları dâhilindeki balık türlerini, avlanma sezonlarını, balıkçılık davranışlarını, balıkçılık tekniklerini ve üretim oranlanını kaydettiği ve 1915 yilında Osmanlıca olarak yayınladı̆̆1 "Türkiye'de Balık ve Balıkçılık" adlı eseridir. Yazar, Doğu Ege'de kefal, barbunya, sardalya, levrek, uskumru, çipura, mürekkep balığ1, ahtapot, 1stakoz, karides, berlam balığı, kolyoz ve orkinoz yakalamak için dalyan, balık ağ1, mıknatıs, çökertme ağ1, olta balıkçılı̆̆1, çanak, g1rgır ve sepetlerin sık kullanıldığına değinmiştir (Deveciyan, 2006; Çakırlar, 2018). 


\section{Tartışma ve sonuç}

Beslenmeye, süslenmeye, boyamaya, kaynak kullanımına, dair ve dinî, ticarî, simgesel ve sihhî amaçlarla Anadolu'da memeli olmayan hayvanların kullanımına prehistorik dönemlerden itibaren rastlanmaktadır. Avcılık, balıkçılık ve toplayıcılıkla yaşamlarını sürdüren Alt Paleolitik Çağ insanları yerleşik hayata geçip tarım yapmayı ve hayvanları evcilleștirmeyi öğrendikleri Neolitik Çağ da dâhil, avcı ve toplayıcı özelliklerini kısmen sürdürmeye devam etmişlerdir. M.Ö. yedinci ve altıncı binde insanların balık avlamaya ve kabuklu deniz böceklerini toplamaya devam ettiği, arkeolojik kazılarda ele geçen buluntulardan anlaşılmaktadır (Gürgör, 2017).

Anadolu'da Paleolitik Çağ'dan beri, balıkların ekonomik ve sosyal yaşamın önemli bir bölümünü olușturduğu bilinse de bu ekonomik sistemlere göreceli katkıları araştırma eksikliği nedeniyle çok net ortaya konulamamıștır. Anadolu'da sadece Karain ve Öküzini mağaralarından Paleolitik balık kemikleri rapor edilmiştir. Daha doğuda, Hallan Çemi Tepesi'nin terminal Epipaleolitik mevkiinde sazangil ve yayın balığ kalıntıları bulunmuştur. Mevcut veriler, Alt Paleolitik insanlarının, balık faunası bakımından zengin olan su kaynaklarının çevresinde konakladığını göstermektedir. Anadolu'da prehistorik ve protohistorik dönemler birlikte değerlendirildiğinde yerleșim yerlerinin ve kasabalarının çoğunun tatlı suya veya denize doğrudan erişimi olduğu bilinmektedir. Balı̆̆ın serbestçe temin edilebilir ve herkes tarafindan yakalanabilir olması, onu sadece günlük bir protein sağlayıcısı değil, aynı zamanda sıkıntı ve kitlık zamanlarında hayatta kalma aracı haline getirmiştir.

Anadolu'nun Paleolitik insanları ve fizikî çevreleriyle olan ilişkileri hakkında bilgilere ulaşıldığı en önemli alan, günümüzden yaklaşık 41 bin ile 29 bin yl öncesine tarihlendirilen Üçağızlı Mağarası'dır. Yapılan çalışmalar, anatomik açıdan modern insanın Afrika'dan Avrasya'ya olan göçlerine yönelik en önemli merkezlerden biri olduğuna işaret etmektedir. Üçağızlı Mağarası'nda yaşamış insanların bilinç düzeylerindeki gelişimin somut bir şekilde ortaya konulduğu verilerin önemli bir bölümü denizel yumuşakçalardan elde edilmiştir. Ortaya çıkarılan Nassarius gibbosula ve Columbella rustica gibi sucul kabuklularında saptanan delinme izleri, bu canlıların süslenme amaçlı kullanıldığını göstermiştir. Deniz kabuklularının beslenme gibi temel bir yaşamsal faaliyet için değil dekoratif amaçlı kullanılmış olması ve farklı teknikler kullanılarak özenle delinmiş olmaları Anadolu antik insanlarının zihnindeki gelişmişliğin en net göstergelerindendir. Bu sebeple de tarihöncesi insanların yaşam ve düşünme şekillerinin anlaşılması açısından büyük önem arz etmektedir (Güleç vd., 2014).

Pınarbaşı Epipaleolitik Çağ katmanlarında ortaya çıarılan deniz canlılarının bir dizi törensel uygulamaların içerisinde kullanıldığı ve bu uygulamaların Güney Levant Natufian ölüm ritüellerini andırdığı anlaşılmıştır (Baird vd., 2013). Pınarbaşı'nda, Akdeniz'den gelen deniz kabukları da bolca bulunmuştur. Kırmızı aşı boyası ile boyanmış deniz kabukları, hayvan dişlerinden yapılma takılar Pınarbaşı insanlarının sosyal organizasyonu hakkında da önemli ipuçları sunmaktadır. Bu durum, insanların sadece söz yoluyla değil bedenleri yoluyla da iletişime geçmiş olduklarına işaret etmektedir. Anadolu süslenme ve sanat konusunda Paleolitik Çağ'dan itibaren pek çok gelişme ve değişime ev sahipliği yapmış, insanları yarattığ1 kültürleri günümüze kadar aktarabilmiştir (Baird, vd., 2013)

Genel olarak, ilgili alanların çevresindeki balıkçılık faaliyetlerinin varlığı açıkça tespit edilebilir. Yakında bir nehri veya denizi olan kıyı kentleri, Ephesos'taki gibi hem deniz hem de tatlı su balıkçılık alanlarından istifade etmiştir. Biraz daha karmaşık olan, kazılan alanın yakınında bu faaliyetlere uygun alanların bulunmadığ1 durumlardır. Böyle durumlarda görülen balık ticareti elbette mevcut karavan yolları boyunca kurulan ticaret sistemlerine bağlı gerçekleşmiştir. Uzun mesafedeki bu ticarî sistemlerin kanıtları, Yenikap1 ve Sagalassos'ta bulunan, hava soluyan yayın balığ1 (Clarias sp.) gibi örneklerde gözlemlenebilmektedir. Dahas1, Sagalassos'ta yapılan çalışmalar, yalnızca Nil'den gelen egzotik balıkların değil, aynı zamanda Akdeniz türlerinin, Epinephelus cinsinin ve farklı uskumrugiller familyasına ait türlerin de ithâl edildiğini ortaya koymaktadır. Eğrez dişında, tüm tatlı su balıklarının kuzey ya da batı bölgelerden dış alım yoluyla ticaretinin yapıldığ düşünülmektedir (Bursa, 2007).

Tanımlanan Akdeniz balık spektrumları, kısmen haliçlerde yapılan kıyı balıkçlığını açıkça göstermektedir. Tespit edilen hayvanların çoğu kıyılara yakın ılıman sığ suları tercih eden ve bu nedenle kolayca balık ağlarına yakalanan dipte yaşayan balıklardır. $\mathrm{Bu}$, en çok karşılaşılan balık familyası olan izmaritgiller (Sparidae) için de geçerlidir. 23 Akdeniz türünden oluşan bu aile, günümüzde de ekonomik açıdan önemini korumaktadır. En sik tespit edilen türlerden biri de çipura (Sparus aurata)dır. Tuna ve Nil dışındaki tüm bölgelerde sıkça kaydedilen başka bir aile, hani balı̆̆ (Serranidae) olup, büyük ölçüde Epinephelus cinsinin avlandığ1 anlaşılmıştır. Bu cinsin türleri ki genellikle orfozlar ele geçirilmiştir; gün boyunca yarıklarda gizlenebilecekleri kayalık ortamları tercih ederler. Serranidae ailesi, Akdeniz'de yaşayan 14 türden oluşmaktadır. Dolayısıyla, nadiren türler düzeyinde tanımlanabilirler. 7 Akdeniz türünden oluşan Sciaenidae familyasının üyesi olan minekoplar düzenli bir şekilde görünür, fakat arkeolojik kazılardan az sayıda ele geçirilmiştir. Levant sahilinde, bugün hâlâ yapıldığı gibi, yetersiz granyöz (Argyrosomus regius) av1 yapılmıstır ve yapılan araştırmalarda sadece 
Beşik Sivritepe'de ele geçirilmiștir. Deniz dibinde yaşayan ve 7 türü Akdeniz sularında olan bir diğer familya kefalgillerin (Mugilidae) yayılım gösterdiği alan Levant ve çevresi olsa da Ephesos'da da ele geçirilmiştir. Sahillerden uzak denizlerde yaşamakla birlikte, zaman zaman sahillere ve açık körfezlere kadar da sokulabilen Scombridae familyasına ait Atlantik mavisi tuna balığ (Thunnus thynnus) da ekonomik anlamda günümüzde olduğu gibi eskiçağlarda da önemli olmuştur.

Hem antik kaynaklar hem de zooarkeolojik veriler, yumurtlamak için göç ettikleri yerlerde avlanan tuna balıklarının kalıntılarını ortaya çıkarsa da van Neer ve Uerpmann, Troia'da bulunan balık kemikleri üzerine yaptıkları çalışmalarında, Prehistorik Dönem Ege dünyasında tuna balığının ana besin maddelerinden biri olduğu yönündeki fikre karşı çıkmışlardır. Çalışmalarında, bu türün kemiklerinin büyük boyutlu olması nedeniyle diğer Akdeniz türlerine nazaran daha kolay tespit edildiğini vurgulamışlardır. Aynı zamanda bu türün bilinen bir örnek olması ve örneklendirme eğiliminin etkisiyle de elle toplanan buluntular arasinda bu balığa ait kalıntıların sayısal bakımdan üstünlük kazanmış olabileceği olasıllğına dikkat çekmişlerdir. Bu nedenlerden kaynaklı olarak da tuna balı̆̆ının erken dönemlerdeki ekonomik değerinin abartıldığını öne sürmüşlerdir (van Neer ve Uerpmann, 1998). Diğer yandan Beşik-Yassitepe'deki faunal buluntular üzerinde çalışmalar yapan Angela von den Driesch, tuna balığının Erken Tunç ve öncesinde de yoğun bir şekilde avlandığını ileri sürmüştür (von den Driesch, 1999).

Kazılarda açığa çıkarılan balık kalıntıları ve balıkçılık malzemeleri (olta iğneleri, balıkçı ağları, bu ağlarda kullanılan ağırlıklar, sabit kapanlar vb.) Tunç Çağı'nda balıkçılıkla ilgili önemli gelişmelerin yaşandığını göstermektedir. $\mathrm{Bu}$ dönemde Akdeniz dünyasında kıyı balıkçılığının hâkim olduğu, bununla birlikte açık deniz balıkçılığına ve göç zamanlarında kıyıya yaklaşan büyük miktardaki balık sürülerini avlamaya yönelik teknolojinin de yaratıldığ1 anlaşılmıştır. Ek olarak, avlanan balıkların bozulmadan uzun süre muhafaza edilebilmeleri amacıyla değişik yöntemlere başvurulduğu görülmüştür. Kilise Tepe ile Sirkeli Höyük'te Akdeniz balığı kalıntılarına rastlanmış olması bu dönemde balık nakliyatının yapıldığına işaret eder. Bu durum aynı zamanda balıkların iç kesimlere ne şekilde taşınmış olabilecekleri sorusunu akla getirmektedir. Sardalya gibi küçük balıkların dayanıksız olmaları nedeniyle işlenmiş halde nakliyatlarının zorunlu olduğu, diğer türlerin ise yukarıdaki örneklerde olduğu gibi 50 km'yi geçmeyen mesafeler arasında taze olarak taşınmış olabilecekleri tahmin edilmektedir (van Neer vd., 2004; van Neer vd., 2005; van Neer ve Waelkens, 2007).

Çanakkale Boğazı'nda gerçekleştirilen tuna balığ1 avları, o dönemde de çok önemli bir ticarî liman olan
İstanbul'un balık ticaretindeki ve beslenmedeki önemine işaretetmektedir(Bursa,2007).Elegeçirilenzooarkeolojik kalıntılardan insanların kimi zaman balıkları başka kentlerden getirttikleri ve semt pazarlarında sattıkları anlaşılmıştır. Yenikapı'da ele geçirilen Afrika kedi balığına ait buluntular Misır/Levant uzun mesafe ticari ilişkilerinin somut bir kanıtıdır. Ayrıca yine aynı alanda afalina (Tursiops truncatus) ve turtak (Delphinus delphis) türlerine ait kalıntıların yağ elde etmek için avlandığ1 düşünülmüştür. Yunusların vücudu yağ ile çevrilidir. Dolayısıyla bu hayvanların yağları için avlandığı bilgisi zooarkeolojik ve antik verilerle örtüşmektedir. MÖ 6-5. binyıllarda İstanbul Boğazı civarında Yenikapı dışında Fikirtepe'deki Neolitik yerleşim yerlerinde yunuslar yaygın bir şekilde kaydedilmiştir (Çakırlar, 2013). Mavi yüzgeçli orkinos MÖ 3. binyıl başlarına tarihlenen Beşik-Yassıtepe yerleşiminde de belirlenmiştir. Von den Driesch'in görüşü, orkinos avının topluluğun ekonomisi ve geçimi açısından yadsınamayacak bir öneme sahip olduğu yönündedir. Ayrıca Beşik-Yassitepe'de kılıç balıklarına (Istiophorus sp.) ait beş parçaya rastlanmıştır. Von den Driesch bu kılıçların kıyıdan uzakta yakalanmış olması gerektiğini düşünmektedir. Beşik-Yassitepe'nin çağdaşı Troia'da görece çok daha az miktardaki orkinos ve kılıç balığı, Beşik-Yassıtepe'nin bu gibi balıkları avlamak açısından Troia'ya göre çok daha avantajlı bir konumda yer aldığını göstermektedir (Uerpmann ve van Neer, 2000).

Daha önce de belirtildiği gibi, tatlı su balıkları Kuzeydoğu Akdeniz'deki bazı yerlerde önemli bir rol oynamıştır. Bazı kıyı kentleri ve şehirleri, az çok karışık deniz ve tatlı su balıkçıllı̆ııın örneklerini göstermiştir. Sagalassos ve Pessinus'un iç bölgelerinde yapılan kazılarda, beklendiği gibi yine çoğunlukla tatlı su balıkları elde edilmiştir. Bu bölgede kullanılan en önemli tatlı su balığı ailesi sazangillerdir. Akdeniz'den yakalandığ1 düşünülen mersin balığ1 da Sagalassos ve Pessinus'ta bulunmuştur (van Neer vd., 2016). Bizans İmparatorluğu zamanında gelişmiş ticaret ağları yoluyla Özellikle Mısır ve Afrika'dan çeşitli balıklar getirtilmiştir (Bursa, 2007).

İnsanların Antik Çă̆'daki dinî inanışları faunal buluntular üzerindeki bir dizi çalışma neticesinde aydınlatılmıştır. Pek çok araştırma yöntemi insanların ruhani yaşamlarını anlamlandırabilmek için yararlı olur. Bu yöntemlerden biri de gerçekleştirilen kurban uygulamalarının analiz edilmesidir. Kazı alanında ele geçirilen kemiklerde tek bir türe ait kemiklerin yoğunluğu ya da alışlmadık türlere ait hayvanların kurban olarak seçilmesi, dönemin insanların inandıkları kutsal varlık hakkında bilgi verebilir. Örneğin, Yunanistan'ın kıyı yerleşimlerinde ele geçirilen balık ve diğer deniz canlıları, kültsel anlamlar içerecek biçimde çeşitli tanrılara (Artemis, Poseidon, Pan, Hermes vb.) 
adanmışlardır (Thedoropoulou, 2014). Anadolu'da ise Antik Çă̆ ritüel uygulamaları daha çok koyun, keçi, sığır ve domuz gibi evcil hayvanlardan oluşmaktadır. $\mathrm{Bu}$ durum insanların bulundukları coğrafik yapıya ve dolayısıyla büyük oranda faydalandıkları hayvanların yoğunluklarıyla ilişkilendirilebilir. Fakat Anadolu'da da nadir de olsa deniz ürünlerinin adak olarak kullanıldığı görülmüştür. Örneğin, Miletos'taki Zeytintepe'de yapılan çalışmalar Afrodit tapınma alanındaki hayvan kurban etme faaliyetlerini ortaya çıkarmıştır. Yapılan çalışmalar sonucunda, tanrıçanın deniz doğasını yansıtan çok miktarda balık ve deniz kabuklusuna rastlanmıştır (Greaves, 2010). Deniz ürünleri tarihöncesi dönemlerden beri insanlar için değerli bir besin kaynağı olmuştur. Kelime anlamı "denizin köpügünden doğan" olan Afrodit'e yapilan adaklarda da verimli deniz ürünleri ve besin kaynakları için tanrıçaya teşekkür etme amacı güdülmüş olabilir. Antik Çağ'da balıkçlık yalnızca beslenme değil ekonomik ve sosyal yaşamın da bir parçası olarak kullanılmıştır. Arkaik Dönem İyonyası'nda ele geçirilen faunal kalıntılar, bölgede balık ve diğer deniz canlılarının bol bulunduğunu ortaya çıkarmıştır. İnsanlar bu canliları (murex) beslenme ve hatta mor boya elde etmek için kullanmışlardır. Saklama yöntemleri gelişmiş olmasına rağmen (kurutma, salamura, füme vb.) balık, bu dönemde büyük bir ihracat ürünü olmamıştır (Greaves, 2010). Balığın yanı sıra kıyı yerleşimlerinden toplanan kabuklu hayvanlar da beslenmeye eșlik etmiștir. Kabuklu hayvanlar beslenmenin yanında büyük olasılıkla boya endüstrisinde de kullanılmışlardır.

Balıkçılık kıyı yerleșimlerinde deniz yoluyla yapılabildiği gibi, göl ve irmaklar aracıllğıyla yapılan balık avcılı̆̆ı da bulunmaktadır. Bu tür balıkçıllı̆ın kontrolünün ise kent ve tapınaklara ait olduğu kabul edilmiştir. Anadolu'daki kentlerin Roma egemenliğine girmesi ile eski ve yeni yerleşimciler arasında balıkçlıktan elde edilen verginin paylaşılmasını gündeme getirmiş, bu durum çeşitli problemleri açığa çıkarmıştır (Bursa, 2007). Ayrıca, antik kaynaklarda Roma Erken Imparatorluk Dönemi'nde balık yetiştirmek için piscinae vivaria olarak adlandırılan özel havuzların inșa edildiği yazılmıștır. Bu havuzlarda yetişen balıklar, kişilerin adlarını değiştirecek kadar önem kazanmışlardır. Örneğin Sergio Orata'nın ismi yetiştirip sattığ1 çipuralardan dolayı Sergius Aurata olurken, Roma Dönemi'ndeki önemli siyasetçilerden olan Lucius Licinius Murena'nın ise adı müren balığına ithafen Lucinius Muraena olarak değiştirilmiştir (Bursa, 2007). Dolayısıyla hayvanların tarihöncesi dönemde olduğu gibi Antik Çağ'da da toplumun siyasî, sosyal ve dinî yaşamına yön veren önemli unsurlardan olduğu veriler doğrultusunda ortaya konulmuştur.

Balık besinsel değerinin dışında erken dönemlerden itibaren özellikle, Mezopotamya ve Misır kültüründeki dinsel ayinlerde de önemli rol oynamıştır. Bu durum mezarlardaki ve dinsel ayinlere ait olduğu belirlenen katmanlardaki balık kemiklerinden anlaşılmaktadır. Buna ilişkin en erken örneklerden birisi ölü gömme ayini ile ilisskilendirilen hayvan kemiklerinin arasında balık kemiklerinin de yer aldığ1 Domuztepe'dir (van Neer vd., 2005). Erken Tunç Çağı'na tarihlenen Tatıka'da da Silibolatlaz Baykara (2019), büyük bir balık olan Barbus lacerta'nın da muhtemelen topluca yenen bir ölü yemeğinin parçası olduğuna dikkat çekmiştir.

\section{Kaynakça}

Aksoy, M., İflazoğlu, N., ve Canbolat, C. (2016). Avrupa aşçllık tarihi: Antik Yunan'dan sanayi devrimine. Journal of Recreation and Tourism Research, 3(1), 54-62.

Badem, A. (2019). Tunç ve Erken Demir Çăglar'nda Maydos Kilisetepe Höyüğ̈ deniz hayvanlarna dayal besin ekonomisi Yayımlanmamış Yüksek Lisans Tezi]. Çanakkale Onsekiz Mart Üniversitesi, Sosyal Bilimler Enstitüsü, Çanakkale.

Baird, D., Asouti, E., Astruc, L., Baysal, A., Baysal, E., Carruthers, D., Fairbain, A., Kabukçu, C., Jenkins, E., Lorentz, K., Middleton, C., Pearson, J., ve Pieie, A. (2013). Juniper smoke, skulls and wolves' tails. The Epipalaeolithic of the Anatolian plateau in its South-west Asian context; insights from Pinarbaş1. Levant, 45(2), 175-209. https://doi. org/10.1179/0075891413Z.00000000024

Bartosiewicz, L., Gillis, R., Girdland Flink, L., Evin, A., Cucchi, T., Hoelzel, R., Vidarsdottir, U., Dobney, K., Larson, G., ve Schoop, U-D. (2013). Chalcolithic pig remains from Çamlibel Tarlasi, Central Anatolia. B. De Cupere, V. Linseele, ve S. Hamilton-Dyer (Ed.) içinde, Archaeozoology of the Near East X: Proceedings of the Tenth International Symposium on the Archaeozoology of South-Western Asia and Adjacent Areas (s. 101-120). (Ancient Near Eastern Studies Supplement Series; Vol. 44). Editions Peeters. http://www.peeters-leuven.be/ boekoverz.asp?nr=9315

Boessneck, J., ve von Den Driesch, A. (1974). The Excavations at Korucutepe, Turkey 1968-1970: Preliminary Report. Part IX: The Animal Remains. Journal of Near Eastern Studies, 33(1), 109-112. https://doi.org/10.1086/372329

Boessneck, J., ve von Den Driesch, A. (1979). Die Tierknochenfunde aus der Neolithischen Siedlung auf dem Fikirtepe bei Kadıköy am Marmarameer. Institut für Paleoanatomie, Domestikationsforschung und Geschichte der Tiermedizin der Universität München, München.

Bursa, P. (2007). Antikesağda Anadolu'da ballk ve ballkęrllk [Yayımlanmamış Doktora Tezi]. İstanbul Üniversitesi, Sosyal Bilimler Enstitüsü, İstanbul.

Çakırlar, C., ve Çilingiroğlu, Ç. (2018). Toplumsal tarihin küçük bir hareketi olarak tarih öncesi Ege'de deniz kaynaklarından faydalanma. TINA, (9), 49-76. http://www.tinaturk.org/ dergi/sayi/09/TINA Dergi Sayi 09-051-078.pdf

Deveciyan, K. (2006). Türkiye'de bahk ve balıkı̧ıllk. Aras Yayıncılık.

Doğer, L., ve Armağan, E. (2014). Bizans Döneminde Prousa (Bursa) ve çevresinde gündelik beslenme üzerine bir deneme. Sanat Tarihi Dergisi, 23(2), 13-48.

Fleet, K. (2014). The Ottoman Economy, c.1300-c.1585. History Compass, 12(5), 455-464. https://doi.org/10.1111/hic3.12166 
Gölbaş, A. (2016). Yerleşim yerlerinin seçiliş biçimleri: Neolitik kıyı yerleşmelerine bir bakış. Journal of International Social Research, 9(46), 317-326. https://doi.org/10.17719/jisr.20164622599

Greaves, A. M. (2010). The land of Ionia: Society and economy in the Archaic Period. Wiley-Blackwell. https://doi. org/10.1002/9781444319224

Güleç, E., Özer, İ., Sağır, M., Baykara, İ., Şahin, S., Açıkkol Yıldırım, A, ve Erkman, C. A. (2014). Anadolu'da İlk Modernler: Üçağızlı Mağarası İnsanları. A. Özfirat, ve U. Çilem (ed.) içinde, Hatay Arkeolojik Kazı ve Arastormalar (s. 21-29). Mustafa Kemal Üniversitesi Yayınları.

Güler, S. (2010). Türk mutfak kültürü ve yeme içme alışkanlıkları. Dumlupinar Üniversitesi Sosyal Bilimler Dergisi, 2(26), 24-30.

Hammer, E. L., ve Arbuckle, B. S. (2017). 10,000 years of pastoralism in Anatolia: A review of evidence for variability in pastoral lifeways. Nomadic Peoples, 21(2), 214-267. https:// doi.org/10.3197/np.2017.210204

Hongo, H. (1997). Patterns of animal husbandry, enviroment, and ethnicity in Central Anatolia in the Ottoman Empire period: Faunal remains from Islamic layers at Kaman- Kalehöyük. Japan Review, (8), 275-307.

Kay, P. (2014). Rome's economic revolution. Oxford University Press.

Onar, V. (2013). Yenikap1 Metro ve Marmaray Kazısı hayvan iskeletleri. Bilim ve Teknik, (Kasım), 18-21.

Reese, D. S. (2006). The exploitation of aquatic resources at Bakla Tepe, Liman Tepe and Panaztepe. E. Özgen ve Ö. Erkanal (ed.) içinde, Hayat Erkeanal'a Armağan, Kültürlerin Yansiması/ Studies in Honor of Hayat Erkanal, Cultural Reflections (s. 626630). Homer Kitabevi.

Reitz, E. J., ve Wing, E. S. (1999). Zooarchaeology. Cambridge University Press.

Silibolatlaz Baykara, D. (2012). Anadolu zooarkeoloji çalışmaları. E. Güleç, İ. Özer, M. Sağır, ve B. Koca Özer (ed.) içinde. Biyolojike Antropoloji, Ankara Üniversitesi Dil ve Tarih Coğrafya Fakültesi 75. Kuruluş Yıl Dönümü Anı Kitabı (s. 71-90). Ankara Üniversitesi Dil ve Tarih-Coğrafya Fakültesi Yayınları.

Stein, G. J. (1998). Medieval pastoral productions systems at Gritille. S. Redford (ed.) içinde, The Archaeology of the frontier in the medieval Near East: Excavations at Gritille, Turkey (s. 181-209). University Museum Publications, University of Pennsylvania.

van Neer, W., ve Uerpmann, M. (1998). Fish remains from the new excavations at Troy. H. Buitenhuis, L. Bartosiewicz, ve A. M. Choyke (ed.) içinde, Archaeozoology of the Near East III. Proceedings of the third international symposium on the archaeozoology of the Southwestern Asia and adjacent areas (s. 243-254). ARCPublicaties 18. https://artiraq.org/static/icaz/ASWAvolumes/ASWA3/aswa3-19-Van-Neer-and-Uerpmann-1998. pdf

van Neer, W., Zohar, I., ve Lernau, O. (2005). The emergence of fishing communities in the Eastern Mediterranean region: A survey of evidence from pre-and protohistoric periods. Paléorient, 31(1), 131-157. https://doi.org/10.3406/ paleo.2005.4793

von den Driesch, A. (1999). Archäozoologische Untersuchungen an Tierknochen aus dem dritten und ersten vorchristlichen Jahrtausend vom Beşik-Yassitepe, Westtürkei. Studia Troica, 9, 456.
Tekkaya, İ. (1992). Panaztepe kazısında ele geçen hayvan kemikleri. Arkeometri Sonuclar Toplantısi, 7, 43-54. http://www. kulturvarliklari.gov.tr/sempozyum pdf/arkeometri/07 arkeometri.pdf

Thedoropoulou, T. (2014). The sea in the temple? Shells, fish and corals from the sanctuary of the ancient town of Kythnos and other marine stories of cult. G. Ekroth, ve J. Wallensten (ed.) içinde, Bones, behaviour \& belief: The <ooarchaelogical evidence as a source for ritual practice in Ancient Greece \& beyond (Actaath-4) (s. 197-222). The Editorial Committee of the Swedish Institutes at Athens and Rome.

Yıldırım, F. (2012). Antik dünyanın en önemli kehanet merkezi söyle bana Didyma. Müze Dergisi, (4), 6-16.

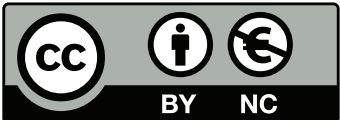

2020. Telif haklar1 yazar(lar)a aittir.

Bu makale Creative Commons Atıf-GayriTicari 4.0 Uluslararası (CC BY-NC 4.0) lisansının hüküm ve şartları altında yayımlanan açık erişimli bir makaledir. 